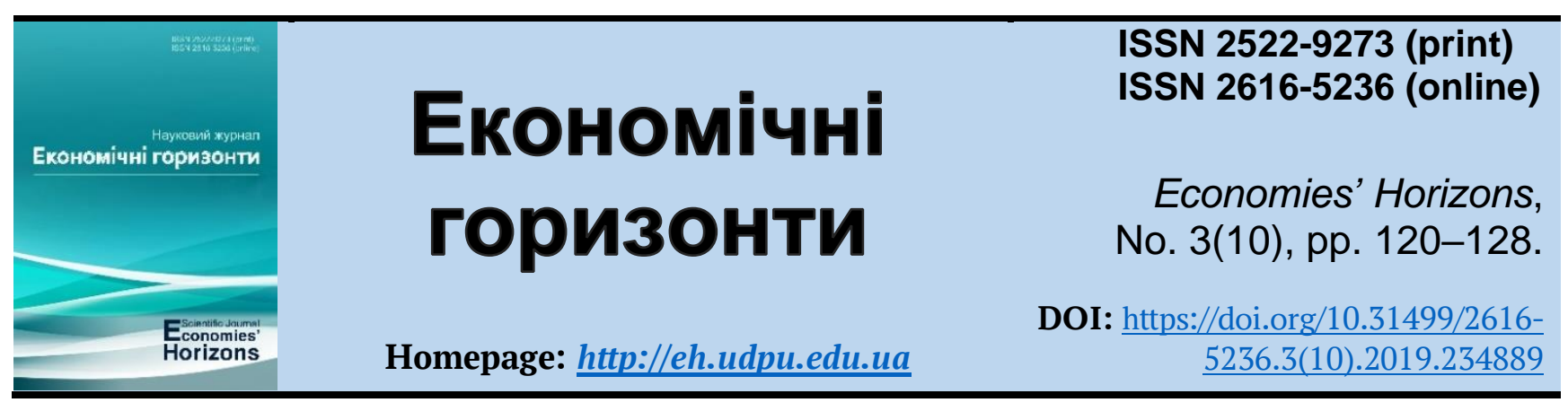

UDC 330.56:656.07

\title{
Digital transformation of the public administration model in the regions
}

\author{
Vladyslav R. Rakipov ${ }^{1}$
}

Received: 10 August 2019

Accepted: 15 September 2019

\begin{abstract}
Rakipov, V. R. (2019), "Digital transformation of the public administration model in the regions", Economies' Horizons, no. 3(10), pp. 120-128, doi:
\end{abstract} https://doi.org/10.31499/2616-5236.3(10).2019.234889

\begin{abstract}
The purpose of the article. The aim of the article is to study the processes of digital transformation of the model of public administration in the regions. Methodology. The theoretical and methodological basis of the study are the scientific works of scientists in the study of the system of digital transformation of public administration in the regions. To achieve this goal, the following research methods were used: theoretical generalization - determination of the main directions of modernization of public administration with the use of digital technologies; methods of statistical analysis - characteristics of the number of public authorities and local governments that provide the opportunity to use the tools of e-democracy. Results. The current state and main trends of digitalization of public administration are studied, which allowed to identify areas and areas of modernization of public administration on the basis of digital transformation, namely: modernization of public services; development of branch e-government; ensuring electronic interaction of state electronic information resources, unification and standardization of electronic registers, state databases, cross-border interaction centers; development of e-democracy and transition to digital document management systems. The level of application of these technologies differs significantly not only at the regional level, but also at the level of municipalities and individual communities and depends primarily on the political will of public administration and local self-government. An analysis of the state of digital transformation of public administration in Odesa region using surveys and studies of national and international rating agencies, which allowed to determine the current comparative state of digital adaptation of public administration in Odesa region and identify the most problematic issues that are typical for other regions and necessary to take into account when developing and implementing a regional strategy for digital transformation of the region for the next planning period, namely: administrative (comparative limited open data on budget information, regulations and procurement, insufficient use of e-democracy elements in management processes); technical (low quality of the basic information and communication infrastructure of e-government; insufficient level of IT support of internal document flow; understaffing of the workforce with the latest technology; problems with communication and quality of the Internet in some areas); organizational (lack of effective coordination, cooperation and control between different departments, functions and subsystems of public administration, low level of data protection) personnel (lack of highly qualified specialists) and financial. Practical meaning. Analysis of the data on the number of public authorities and local governments that provide the opportunity to use the tools of e-democracy will determine the prospects for further work for public authorities. Prospects for further research. Accelerating the transition to the

\footnotetext{
${ }^{1}$ Higher Education Institution "International University of Business and Law"; Doctoral Candidate; ORCID ID: https://orcid.org/0000-0002-1386-5156; e-mail: management@nuos.edu.ua.
} 
digital administration model requires reengineering management systems, processes and functions in accordance with the capabilities provided by new technologies, in particular using a process approach to management and networking, creating a single regional platform, interactive databases, implementation of electronic democracy in decision-making processes.

Keywords: digital transformation, public administration, information and communication technologies, digitalization.

JEL Classification: L86, R10, R23.

Number of references: 14; number of tables: 2; number of figures: 0; number of formulas: $\mathbf{0 .}$

\section{Цифрова трансформація моделі публічного управління у регіонах}

\section{Владислав Русланович Ракіпов ${ }^{1}$}

Стаття надійшла: 10.08 .2019 Стаття прийнята: 15.09 .2019
Rakipov V. R. Digital transformation of the public administration model in the regions. Економічні горизонти. 2019. № 3(10). C. 120-128. DOI: 10.31499/26165236.3(10).2019.234889

Анотація. Метою статті є дослідження процесів цифрової трансформації моделі публічного управління у регіонах. Методологія. Теоретичною і методологічною основою дослідження $є$ наукові праці вчених у дослідженні системи цифрової трансформації публічного управління у регіонах. Для досягнення поставленої в роботі мети були використані такі методи дослідження: теоретичне узагальнення - визначення основних напрямів модернізації публічного управління з використанням цифрових технологій; методи статистичного аналізу - характеристики кількості органів державної влади та місцевого самоврядування, що надають можливість використання інструментів електронної демократії. Результати. Досліджено поточний стан та основні тенденції цифровізації публічного управління, що дозволило виділити напрямки та сфери модернізації публічного управління на основі цифрової трансформації, а саме: модернізація публічних послуг; розвиток галузевого електронного урядування; забезпечення електронної взаємодії державних електронних інформаційних ресурсів, уніфікація та стандартизація електронних реєстрів, державних баз даних, центрів транскордонної взаємодії; розвиток електронної демократії та перехід на системи цифрового документообігу. Рівень застосування вказаних технологій суттєво відрізняється не тільки на рівні регіонів, а також на рівні муніципалітетів та окремих громад і залежить насамперед від політичної волі органів публічного управління та місцевого самоврядування на місцях. Проведено аналіз стану цифрової трансформації публічного управління в Одеській області з використанням результатів опитувань та досліджень національних і міжнародних рейтингових агентств, що дозволило визначити поточний порівняльний стан цифрової адаптації публічного управління на Одещині та виокремити найбільш проблемні питання, що є характерними і для інших регіонів та які необхідно врахувати при розробці і реалізації регіональної стратегії цифрової трансформації області на наступний плановий період, а саме: адміністративні (порівняна обмеженість відкритих даних щодо інформації про бюджет, регуляторні акти та закупівлі, недостатній рівень використання елементів електронної демократії в управлінських процесах); технічні (низька якість базової інформаційнокомунікаційної інфраструктури електронного урядування; недостатній рівень IT забезпечення внутрішнього документообороту; недоукомплектованість робочих міць новітньою технікою; проблеми зі зв'язком та якістю Інтернету на окремих територіях); організаційні (відсутність дієвої координації, співпраці та контролю між різними відділами, функціями і підсистемами публічного управління, низький рівень захисту даних) кадрові (брак висококваліфікованих спеціалістів) та фінансові. Практичне значення. Аналіз даних кількості органів державної влади та місцевого самоврядування, що надають можливість використання інструментів електронної

\footnotetext{
${ }^{1}$ Заклад вищої освіти «Міжнародний університет бізнесу і права»; здобувач; ідентифікатор ORCID: https://orcid.org/0000-0002-1386-5156; e-mail: management@nuos.edu.ua.
} 
демократії дозволить визначити перспективи подальшої роботи для органів публічної влади. Перспективи подальших досліджень. Прискорення переходу до моделі цифрового адміністрування потребує реінжинірингу систем управління, процесів та функцій у відповідності до можливостей, що надають нові технології, зокрема з використанням процесного підходу до управління та формування мережевих зв'язків, створення єдиної регіональної платформи, інтерактивних баз даних, впровадження елементів електронної демократії у процеси прийняття рішень.

Ключові слова: цифрова трансформація, публічне управління, інформаційнокомунікаційні технології, діджиталізація.

Кількість джерел: 14; кількість таблищь: 2; кількість рисунків: 0; кількість формул: 0.

\section{Introduction.}

Modern conditions characterized by the rapid spread of digital technologies in all areas of socio-economic space create the preconditions for a radical overhaul of the model of public administration at the state level and local government to ensure their effectiveness, efficiency in response to new challenges, democratic procedures. and solutions using modern technologies.

\section{Literature review.}

Analysis of recent research and Analysis of recent research and publications on the problem. Among modern economists, whose research is devoted to the problems of digital transformation of the model of public administration, it is necessary to note scientific works, in particular: S. Pantsyr (ed.) (2015), I. Kramarenko (2017), Yu. Solomko (2018), A. Olenin (2019), O. Slobozhan (2019), and others. However, the complexity and versatility of this study requires a study of the digital transformation of the model of public administration in the regions.

\section{Methodology.}

The theoretical and methodological basis of the study are the scientific works of scientists in the study of the system of digital transformation of public administration in the regions. To achieve this goal, the following research methods were used: theoretical generalization - determination of the main directions of modernization of public administration with the use of digital technologies; methods of statistical analysis - characteristics of the number of public authorities and local governments that provide the opportunity to use the tools of e-democracy.

\section{Research objectives.}

The aim of the article is to study the processes of digital transformation of the model of public administration in the regions.

\section{Results and discussions.}

We support the opinion of scientist G. Maryanenko that "among the many modern information and communication technologies that define this process, a special place is occupied by the model of digital public administration, the effectiveness of which depends on many factors of political, social, economic, informational, scientific and methodological, organizational and regulatory nature. Without taking into account these factors, determining their priority and establishing relationships, it is impossible to form a scientifically sound public policy for public administration in the field of digital transformation and development of the digital economy as a whole" (Maryanenko, 2017).

It should be noted that the digitalization of public administration today is the main priority of digital transformation and the leading direction of public reform in Ukraine.

The basis for the formation of a new model of public administration on the basis of digitalization is the introduction of egovernment at all levels of public administration. As stated in the Concept, "E-government is a form of public administration that promotes efficiency, openness and transparency of public authorities and local governments using information and telecommunications technologies to form a new type of state focused on meeting the needs of citizens. The introduction of e-government is a basic precondition for building an efficient digital 
economy and digital market in Ukraine and its further integration into the EU Digital Single Market Strategy" (Cabinet of Ministers of Ukraine, 2017).

Modernization of public services involves the development of public services through the use of appropriate digital platforms, building communication links between government, business and the population and the introduction of electronic services in all spheres of public life (education, medicine, social protection, housing and communal services), and integrated electronic services for basic business situations (registration, licensing, tax administration, issuance of permits, legal support, etc.).

The construction of electronic communications between the government, public authorities and citizens, according to the guidelines presented in the handbook on egovernment in communities, will take place in the following areas:

“- G2G ("government to government")" - a sector of electronic interaction between authorities. Includes the organization of electronic document management and data exchange between government electronic registers on the basis of the principle of unification, interchangeability and compatibility (socalled principles of interoperability);

- G2B ("government to business") - a sector of electronic interaction between public authorities and economic entities to support and develop business through ICT through the provision of administrative and other services, business participation in the implementation of state policies and programs;

- G2C ("government to citizens") - a sector of electronic interaction between public authorities and citizens in order to provide citizens with quality and timely public services, citizen participation in public policymaking and the electoral process, evaluation and control of activities public authorities, etc. The development of the G2C sector makes it possible to move to a qualitatively new level of communication between the state and citizens - access to electronic administrative services 24/7/365 (24 hours a day, 7 days a week, 365 days a year), which significantly improves the service of the latter. meeting the needs of public services" (Vinnytsia Regional Association of Local SelfGovernment Bodies, 2019).

Important components of modernization of public administration and local selfgovernment on the basis of digitalization are the provision of electronic interaction of state electronic information resources, unification and standardization of electronic registers, state databases, cross-border interaction centers, etc. That is, one of the important issues that needs to be addressed today for the effective functioning of public administration in the digital space is the digitization of data and the creation of effective iterative links between governments both vertically and horizontally. The organization of the work of state statistics and the form of statistical reports also need to be improved in this aspect.

Today, the sectoral e-government is developing quite rapidly, namely: e-commerce, e-banking, e-medicine (including telemedicine), e-education (distance education), the introduction of e-government technologies in the transport and logistics sector, the tax service, at customs, in courts, etc.

The main direction of modernization of public administration with the use of digital technologies is the creation of digital document management, optimization of decisionmaking systems and resource allocation, ensuring democracy and transparency of procedures.

Given the current situation and development strategy of Ukraine and the regions, the basic functions of e-government include quality support and support of major reforms, namely: medical, educational, administrative, financial, etc. To this end, appropriate digital platforms, services and products are being created and implemented, which should be integrated into a single digital space to ensure state regulation and oversight of the implementation, achievements and consequences of ongoing reforms.

As Yu. Solomko notes, "To move to egovernment, it is necessary that:

- authorities used the Internet and provided interactive services that would allow an 
individual or legal entity to fill out various forms, forms, ask questions, make appointments, look for work, etc. by visiting the relevant official website. Feedback was provided via email;

- it was possible to receive administrative services via the Internet (electronic services): obtaining licenses, permits, certificates, filing declarations, paying fines, applying for social issues, etc. This, in turn, requires increased security of e-government infrastructure, which can usually be achieved through a comprehensive system of information security, the use of electronic signatures, certificates, etc.;

- the authorities created special web portals that would allow people from one service to another without having to re-identify themselves" (Solomko, 2018).

Statistics show that Ukraine already has some achievements in the introduction and use of e-democracy tools in public authorities (Table 1).

\section{Table 1. Number of public authorities and local governments that provide the opportunity to use the tools of e-democracy in 2019}

\begin{tabular}{|l|c|c|c|c|c|}
\hline \multicolumn{1}{|c|}{ Indexes } & Total & $\begin{array}{c}\text { State } \\
\text { authorities }\end{array}$ & $\begin{array}{c}\text { Judicial } \\
\text { system }\end{array}$ & $\begin{array}{c}\text { State organiza- } \\
\text { Local } \\
\text { tions (institu- } \\
\text { tions, estab- } \\
\text { lishments) }\end{array}$ \\
\hline $\begin{array}{l}\text { Number of institutions that had } \\
\text { access to the Internet, units }\end{array}$ & 17,678 & 5,102 & 695 & 10,584 & 1,297 \\
\hline $\begin{array}{l}\text { Share of institutions that had ac- } \\
\text { cess to the Internet in the total } \\
\text { number of institutions that partici- } \\
\text { pated in the survey, \% }\end{array}$ & 94.7 & 92.5 & 87.9 & 96.6 & 92.8 \\
\hline $\begin{array}{l}\text { Number of institutions that pro- } \\
\text { vided the opportunity to use e- } \\
\text { democracy tools "E-appeal", "E- } \\
\text { petition", "E-consultation", "Par- } \\
\text { ticipation budget (public budget)" } \\
\text { and other e-democracy tools, units }\end{array}$ & 3,853 & 1,326 & 568 & 1,818 & 141 \\
\hline In \% to all institutions & 21.8 & 26.0 & 81.7 & 17.2 & 10.9 \\
\hline of them & & & & & \\
\hline "E-appeal" & 3,365 & 1,253 & 565 & 1,417 & \\
\hline E-petition & 678 & $\mathrm{x}$ & $\mathrm{x}$ & 659 & \\
\hline "E-consultation" & 358 & 145 & - & 210 & \\
\hline $\begin{array}{l}\text { "Participation budget (public } \\
\text { budget)" }\end{array}$ & 416 & 31 & $\mathrm{x}$ & 385 & $\mathrm{x}$ \\
\hline
\end{tabular}

Source: State Statistics Service of Ukraine (2019).

As of the end of 2019, the share of government agencies and organizations that had access to the Internet was over $90 \%$. At the same time, the highest level of access was observed in local governments over $96.6 \%$ ). The total share of institutions that provided the opportunity to use e-democracy tools " $E$ appeal”, “E-petition”, “E-consultation”, "Participation budget (public budget)" and other e-democracy tools was $21.8 \%$. The largest (over $81.7 \%$ ) tools of e-democracy were used by the judiciary. The level of application of edemocracy instruments in local governments and state bodies respectively remains low at 17.2 and $26 \%$.

In order to digitalize local selfgovernment, the positions of deputy heads of regional state administrations for digital transformation have been introduced in each oblast administration. This is the CDTO (Chief Digital Transformation Officer), or heads of digital transformation. The main task of these 
managers is to implement the changes taking place in the state on the ground. The Deputy Head of the Regional State Administration for Digitalization will deal with the digital transformation of the Regional State Administration, assistance to local governments in implementing new state digital services, expanding the list of services provided in the Centers for the Provision of Administrative Services (CPAPs) of certain areas, digital education and Internet access to settlements (Administrative Services Reform Portal, 2019).

Implementation of the tasks defined in the strategy requires appropriate organizational and technical support at the level of public authorities and local governments in the form of new, adapted to digital management of network-type structures, changing qualification requirements for positions and revision of job descriptions, elimination of double subordination and data duplication. effective integration of public service information systems, optimized information flows and decision-making methods.

A revolutionary step in ensuring digital transformation in Ukraine is the creation of a digital application “Action”, which provides electronic access to basic identity documents and property rights: ID-card, biometric passport, driver's license, technical passport, insurance policy, student card. So far, the Ministry of Finance has released an updated version - Action 2.0. Document sharing is the most important update of Action 2.0. This is a real digital revolution for the state. Ukrainians will be able to send copies of documents (passport, TIN, birth certificate) by clicking "OK" on the push message in the Action application. This will greatly simplify obtaining banking or postal services, checking into a hotel and hundreds of other life situations. The update also includes the ability to share the technical passport for the car with another person - a display of the appropriate user. Millions of users were waiting for this function / According to the Ministry of Digital Transformation, more than 5 million Ukrainians have already downloaded the digital application.

In order to overcome the main barriers and intensify the process of digital adaptation of public administration of cities and communities on the basis of e-government, the representatives of the Association of Ukrainian Cities have developed the following recommendations:

“- conducting a series of informational and educational campaigns aimed at promoting e-services;

- development of a standard Program for the Development of e-democracy implementation strategy;

- synchronization and unification of existing services in order to eliminate duplicates;

- development and implementation of a single standard site-platform for small towns (population from 10,000 to 100,000 people), which should have a standard database of available e-services. In particular, these include: e-document management - a package of e-services for citizens by the authorities; modules for condominiums and local selfgovernment; e-office of the resident, which will include access to social services (schools, kindergartens, hospitals, housing and communal services, etc.); infrastructure services; budget; e-petitions.

- dissemination of best practices in the information field of implementation of estrategy elements at the local level."

In order to accelerate the process of digitalization of public services, in particular at the level of territorial communities, Ukraine has introduced an international project under the U-LEAD program. The project aims to improve the provision of public services in local governments of Ukraine by developing and implementing an electronic interaction system, information systems and administrative services. The expected result is the creation of up to 600 administrative service centers by the end of the project. In 2021, when the project is completed, Ukraine will be able to provide hundreds of public services entirely in electronic form. U-LEAD with Europe is funded by the EU and its Member States Sweden, Denmark, Estonia, Germany, Poland and Slovenia. The program lasts from 2016 to 2021 (e-Governance Academy Foundation, 
2019).

Despite the obvious advantages, there are a number of problems that accompany the processes of digital transformation of public administration. In particular, S. Chukut and $\mathrm{K}$. Buryachenko identifies the following main issues that need to be considered in the implementation of the strategy:

- the problem of compatibility - all the various technologies of e-government, implemented in both public authorities and local governments, must be compatible with each other;

- the problem of national security - the more transparent and open the activities of public authorities and local governments, thanks to modern electronic document management systems and their interaction with other systems, the greater the likelihood of using this information to the detriment of our country's sovereignty;

- the problem of national identity - attempts to introduce e-government technologies, using the developments of foreign companies, unifying them without taking into account the specifics of our country, can lead to the loss of national identity. One manifestation of this is the user language (mostly English or Russian) used in these developments;

- the problem of economic security - insufficient protection of information and reports of Ukrainian companies and enterprises from threats from unfair competitors;

- the problem of privacy protection - the formation of various databases by public authorities and local governments, without clearly defining the conditions of access to this information and its use, will inevitably lead to loss of public confidence in these bodies and failure to accept any innovations in e-government;

- the problem of responsibility - most employees of both public authorities and local governments, and the service sector are not responsible for providing access to interested organizations and citizens of personal data of other citizens;

- the problem of "force majeure" circumstances - the transfer of all documenta- tion in electronic format without a backup, as well as the transition to training of specialists using modern ICT in various fields of knowledge, under force majeure can lead to complete state collapse (Chukut and Buryachenko, 2018).

According to a study of urban transparency conducted by the international organization Transparent Cities, Odesa, despite some problems with data transparency, improves its transparency rating every year. In particular in 2019, the level of transparency of the city was estimated at 57.6 points (which corresponds to 20th place in the ranking of the rated 100 cities of Ukraine), while in 2017 it was only 32.5 points (29th place). Over the last three years, the positions on the following components of the rating have improved: information on the budget ( +3 points), access to finance, material assistance, grants (+4 points), information on public procurement $(+5)$. Transparency of personnel policy $(+2)$, information on communal property management $(+2)$ and other components within 1-2 points. The most problematic issues for public access and digital display are: the provision of social services, housing policy, the activities of city authorities and decisions, the issue of transparency of public procurement. The dynamics of the main indicators of government transparency since the beginning of the monitoring in Odesa are presented in Table 2.

As you can see from the table, in 2019 the level of transparency in Odesa has significantly improved compared to estimates for 2017. In particular, the total number of points increased by 25.1 , which allowed to move in the ranking by 19 steps higher. The highest score (11.9) was added to the ranking of information on investment and economic development. Problematic issues remain: social services, information on communal property management, housing policy and education.

The main factors that will stimulate the processes of digital adaptation in the region are primarily the presence of political will and willingness of public authorities to change, initiatives to optimize the functions of civil servants in the context of new management 
realities, high level of training and digital literacy, development of effective, financially and organizationally sound programs, digitization of public administration.

\section{Table 2. Dynamics of indicators of transparency of local government in Odesa} for 2017-2019

\begin{tabular}{|l|c|c|c|c|}
\hline \multicolumn{1}{|c|}{ Indicators, points } & $\mathbf{2 0 1 7}$ & $\mathbf{2 0 1 8}$ & $\mathbf{2 0 1 9}$ & Increase \\
\hline Place in the ranking & 39 & 42 & 20 & -19 \\
\hline Total score & 32.5 & 40.7 & 57.6 & +25.1 \\
\hline Information on the work of local government & 6.6 & 5.0 & 4.3 & -2.3 \\
\hline Access and participation & 6.0 & 4.5 & 6.1 & +0.1 \\
\hline Procurement & 2.0 & 1.5 & 2.5 & +0.5 \\
\hline Housing policy & - & 0.5 & 0.5 & +0.5 \\
\hline Budget process & 3.0 & 3.7 & 3.5 & +0.5 \\
\hline Financial and material assistance, grants & 1.0 & 3.5 & 5.0 & +4.0 \\
\hline Social services & - & - & 0.5 & +0.5 \\
\hline Personnel issues & 4.0 & 4.0 & 2.5 & -1.5 \\
\hline Anti-corruption policy and professional ethics & 0.3 & 3.0 & 2.7 & +2.4 \\
\hline Land use and construction policy & 3.7 & 5.4 & 5.5 & +1.8 \\
\hline Utilities & 2.4 & 5.6 & 7.2 & +4.8 \\
\hline Communal property & 1.0 & 1.0 & 2.5 & +1.5 \\
\hline Education & 2.5 & 3.0 & 3.0 & +0.5 \\
\hline Investment and economic development & - & - & 11.9 & +11.9 \\
\hline
\end{tabular}

Source: Transparent Cities (2019); Odesa Regional State Administration (2019).

Studies have shown that despite the acceleration of the transition of the economy and society to the new digital reality, the processes of modernization of public land management are carried out in an evolutionary way, leading to a digital divide between the needs of the population, economy and society. calls. The current management system is being modernized in accordance with the requirements of administrative reform, but in most cases the decision-making methods, administrative functions, procedures and other elements of management are carried out according to the old schemes, which are not sufficiently adapted to digital capabilities.

\section{Conclusions.}

The current state and main trends of digitalization of public administration are studied, which allowed to identify areas and areas of modernization of public administration on the basis of digital transformation, namely: modernization of public services; development of branch e-government; ensuring electronic interaction of state electronic information resources, unification and standardization of electronic registers, state databases, cross-border interaction centers; development of e-democracy and transition to digital document management systems. The level of application of these technologies differs significantly not only at the regional level, but also at the level of municipalities and individual communities and depends primarily on the political will of public administration and local self-government.

An analysis of the state of digital transformation of public administration in Odesa region using surveys and studies of national and international rating agencies, which allowed to determine the current comparative state of digital adaptation of public administration in Odesa region and identify the most problematic issues that are typical for other regions and necessary to take into account when developing and implementing a regional strategy for digital transformation of the region for the next planning period, namely: administrative (comparative limited open data on budget information, regulations and procurement, insufficient use of e-democracy elements in management processes); technical (low quality of the basic information and 
communication infrastructure of egovernment; insufficient level of IT support of internal document flow; understaffing of the workforce with the latest technology; problems with communication and quality of the Internet in some areas); organizational (lack of effective coordination, cooperation and control between different departments, functions and subsystems of public administration, low level of data protection) personnel (lack of highly qualified specialists) and financial.

\section{References}

Administrative Services Reform Portal (2019), "Development of the network of Centers for the Provision of Administrative Services for the first half of 2019", available at: https://cnap.in.ua/monitoring-1-half-of2019 (Accessed 3 August 2019).

Cabinet of Ministers of Ukraine (2017), Order of the Cabinet of Ministers of Ukraine "On approval of the Concept of e-government development in Ukraine", available at: https://zakon.rada.gov.ua/laws/show/649-2017-\%D1\%80\#Text (Accessed 3 August 2019).

Chukut, S. and Buryachenko, K. (2018), "Blockchain or system of the electronic document circulation: modern trends of implementation in the bodies of executive power of Ukraine", Investytsiyi: praktyka ta dosvid, vol. 1, pp. 70-76.

e-Governance Academy Foundation (2019), "U-LEAD support project EGOV4UKRAINE”, available at: https://ega.ee/ru/project/u-lead (Accessed 3 August 2019).

Kramarenko, I. (2017), "Social-economic and intellectual development of Ukraine: Regional and national aspect”, Danish Scientific Journal, no. 1, pp. 20-27.

Maryanenko, G. I. (2017), "Tomorrow without politicians - introducing a mechanism of public administration by electronic government and electronic (digital) direct democracy", Public administration: improvement and development, no. 2, available at: http://www.dy.nayka.com.ua/?op=1\&z=1053 (Accessed 3 August 2019).

Odesa Regional State Administration (2019), "Strategic action plan of the Head of the Odesa Regional State Administration 2017-2019. Smart region", available at: https://oda.odessa.gov.ua/statics/pages/files/5b0287ae92db6.pdf (Accessed 3 August 2019).

Olenin, A. (2019), "Internet laying, digital literacy and new services: How the regions will be digitalized", available at: https://lb.ua/society/2019/02/27/478651_prokladennya internetu tsifroviy.html (Accessed 3 August 2019).

Pantsyr, S. (ed.) (2015), Elektronna Demokratiia. Bila knyha derzhavnoi polityky [Electronic democracy. White paper on public policy], State Agency for e-Government of Ukraine, Kyiv, Ukraine, 43 p., available at: http://dialog.lviv.ua/wp-content/uploads/2016/02/Elektronna-demokratiya.pdf (Accessed 3 August 2019).

Slobozhan, O. (2019), "E-democracy - a new vector of development of territorial communities", available at: https://www.auc.org.ua/sites/default/files/tezy slobozhan e-democr.pdf (Accessed 3 August 2019).

Solomko, Yu. I. (2018), "E-government: Concept, essence, principles and directions of development", Efficiency of public administration, vol. 2(55), part 1, pp. 135-143, doi: https://doi.org/10.33990/20704011.55.2018.146726.

State Statistics Service of Ukraine (2019), "Statistical information”, available at: http://www.ukrstat.gov.ua (Accessed 3 August 2019).

Transparent Cities (2019), “Odesa”, available at: https://transparentcities.in.ua/city/odesa (Accessed 3 August 2019).

Vinnytsia Regional Association of Local Self-Government Bodies (2019), "Introduction of e-government and edemocracy at the local level”, available at: http://sg.vn.ua/wp-content/uploads/2019/12/Vprovadzhennyaelektronnogo-vryaduvannya-ta-elektronnoyi-demokratiyi-na-mistsevomu-rivni.pdf (Accessed 3 August 2019).

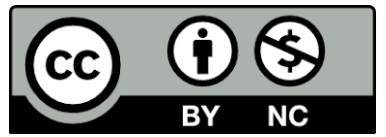

Цей твір ліцензовано на умовах Ліцензії Creative Commons «/з Зазначенням Авторства - Некомерційна 4.0 Міжнародна» (CC BY-NC 4.0). This is an open access journal and all published articles are licensed under a Creative Commons "Attribution-NonCommercial 4.0 International" (CC BY-NC 4.0). 